\title{
PALYNOLOGICAL ASSEMBLAGE FROM APTIAN/ALBIAN OF THE SERGIPE BASIN: PALEOENVIRONMENTAL RECONSTRUCTION
}

\author{
MARCELODEARAUJOCARVALHO \\ Depto. de Geologia e Paleontologia, MNRJ, Quinta da Boa Vista s/n, 20940-040, Rio de Janeiro, RJ, Brasil. \\ mcarvalho@mn.ufrj.br
}

\begin{abstract}
Palynological analysis was carried out on 272 core samples from two wells (GTP-17-SE and GTP-24-SE) in the Sergipe basin with the aim of reconstruction the paleoenvironment of the upper Aptianmiddle Albian interval. The Paleoecological studies based on the abundance and composition of all palynomorph genera revealed four assemblages. The stratigraphic distribution of these assemblages allowed the definition of seven ecophases. The palynological assemblage reflects the paleoenvironmental history of the succession that is marked by the progressive late Aptian-middle Albian transgression into the area. The data, in particular the ecophases, confirm that the change from a brackish lagoon to open marine environment was controlled by sealevel during deposition of Muribeca Formation, and dominantly by a progressive sea-level rise during the beginning of the Riachuelo Formation deposition.
\end{abstract}

Key words: palynology, paleoenvironmental reconstruction, Cretaceous.

RESUMO - Com a finalidade de reconstruir os ambientes deposicionais com base em análise palinológica de uma seção aptiana-albiana da plataforma carbonática-siliciclástica da bacia de Sergipe, foram identificadas e analisadas quatro associações palinológicas de 253 amostras de dois poços. A distribuição estratigráfica das quatro associações permitiu identificar sete ecozonas que refletem uma progressiva transgressão marinha aptina-albiana na área estudada. Esses dados confirmam uma mudança paleoambiental de laguna para marinho aberto controlada pela variação do nível do mar durante a deposição da Formação Muribeca e dominantemente por uma subida do nível do mar durante o começo da deposição da Formação Riachuelo.

Palavras-chave: palinologia, reconstrução paleoambiental, Cretáceo.

\section{INTRODUCTION}

The Aptian-Albian succession of the Sergipe basin is represented by a mixed carbonate-siliciclastic platform system (Muribeca and Riachuelo formations), corresponding to a transitional phase between the rift phase and the beginning of the open marine phase. These phases reflect the progressive separation of the African and South American continents, which led to sea-level changes basins of the continental margin. However, on a short-term view variations of the sea-level curve are observed and hence variations in local paleoenvironments. The interpretation of these different paleoenvironments based on composition and diversity of palynomorph indicates a transgressive trend upward.

\section{GEOLOGICAL SETTING}

The Sergipe basin, which forms the southern part of the Sergipe-Alagoas basin in northeastern Brazil, is a structurally elongated marginal basin between coordinates $9^{\circ}-11^{\circ} 30^{\prime} \mathrm{S}$ and $37^{\circ}-35^{\circ} 30^{\prime} \mathrm{W}$. Onshore the basin is $16-50 \mathrm{~km}$ wide and $170 \mathrm{~km}$ long and covers an area of $6000 \mathrm{~km}^{2}$ and the offshore portion comprises an area of about $5000 \mathrm{~km}^{2}$ (Figure 1).
The Sergipe basin belongs to the class of sedimentary basins related to passive continental margins. According to Ojeda \& Fugita (1976) and Ojeda (1982) the tectonic evolution of the Sergipe basin can be divided into five main phases: intracratonic, pre-rift, rift (earliest Cretaceous to early ?Aptian), transitional (Aptian), and a marine drift phase (late Aptian to Recent).

\section{Study succession}

The succession studied in wells GTP-17-SE and GTP-24SE comprises part of the Muribeca (transitional phase) and Riachuelo (open marine phase) formations (Figure 2).

In well GTP-17-SE (Figure 3) the succession has a thickness of ca. $450 \mathrm{~m}$ and is subdivided into: (1) the Muribeca Formation, represented by the evaporitic Ibura Member (63 $\mathrm{m})$ and the carbonate-siliciclastic platform system of Oiteirinhos Member ( $80 \mathrm{~m}$ ); and (2) the Riachuelo Formation, represented by the fine to conglomeratic sandstones intercalated with greenish grey shales of Angico Member (312 m).

In well GTP-24-SE, the succession reaches $400 \mathrm{~m}$ and is subdivided into (1) the Muribeca Formation, with the Ibura Member (26.9 m) and the Oiteirinhos Member (126.9 m); and 
(2) the Riachuelo Formation with the intercalations of shales and calcilutites of the Taquari Member (247 m).

\section{PALYNOSTRATIGRAPHY}

The biostratigraphical information used in this study was derived from the studied wells and the biostratigraphical framework of Regali \& Santos (1999). Four successive biostratigraphic intervals are identified for the upper Aptianmiddle Albian of the studied succession.

The Sergipea variverrucata zone and the Equisetosporites maculosus and Dejaxpollenites microfoveolatus sub-zones from the Regali \& Santos (1999) were recognized herein (Figure 3). The major difference from the study by Regali \& Santos (1999) for the two studied wells, is the recognition of the middle Albian (Classopollis echinatus Zone) characterized by the first occurrence of Elaterosporites klaszi? (Carvalho, 2001). However, it was recorded from samples that were not studied by Regali \& Santos (1999).

\section{MATERIALAND METHODS}

The study was carried out using 253 core samples from two wells (101 from GTP-17-SE and 152 from GTP-24-SE) drilled by Petromisa/Petrobras (the Brazilian state-owned oil company) in the Santa Rosa de Lima and Carmópolis areas in Sergipe (see Figure 1).

The method applied of palynological preparation used by Petrobras was compiled by Uesugui (1979) after, e.g.,
Erdtman (1969), and Faegri \& Iversen (1966), where all the mineral constituents are destroyed by hydrochloric and hydrofluoric acids before heavy-liquid separation. The remaining organic matter is sieved through a $10 \mu \mathrm{m}$ mesh prior to mounting on slides.

\section{Palynological analysis}

The qualitative analysis consisted basically of the identification and recording of the palynomorphs in the samples. The samples were analyzed under a transmitted light microscope. The quantitative analysis was based on the first 200 palynomorphs counted for each slide. This analysis was the basis for the establishment of the palynomorph distribution.

\section{Paleoecological analysis}

The paleoecological analysis was carried out using multivariate statistical methods (cluster analysis and Pearson correlation) to identify the ecological similarity between palynomorph assemblages from different depositional settings. In addition, the Palynological Marine Index (PMI) was employed.

\section{Cluster analysis and Pearson coefficient}

Cluster analysis was employed based on abundance and composition, in order to establish groupings and to recognize the relationship between the taxa (palynological analysis). To identify the divisions of the studied succession based on palynology approach, Q- and R-mode cluster analyses were performed on counts of palynomorphs. This cluster analysis

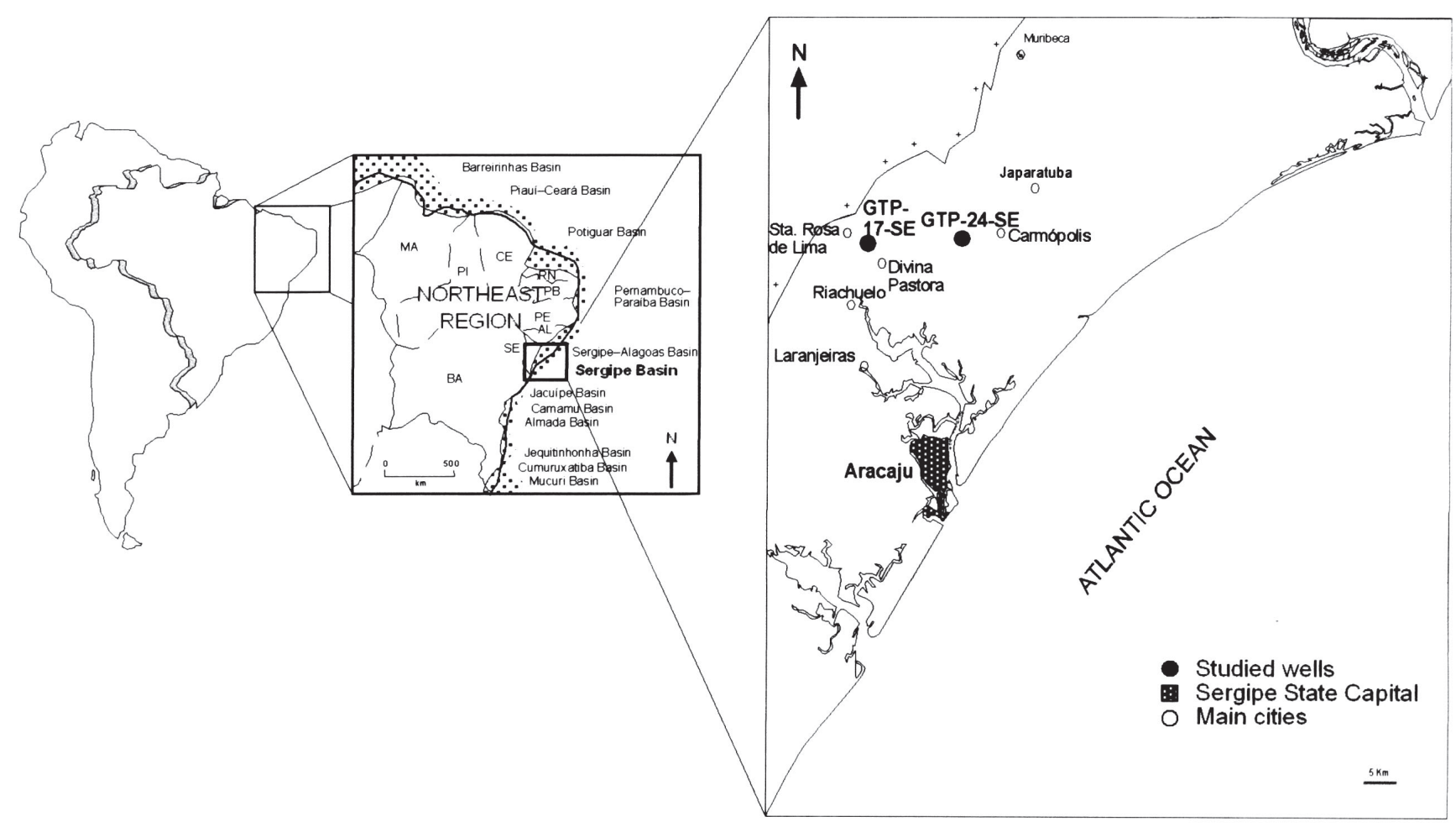

Figure 1. Location map of the marginal basins of northeastern Brazil, including the studied wells (adapted from Seeling, 1999). 


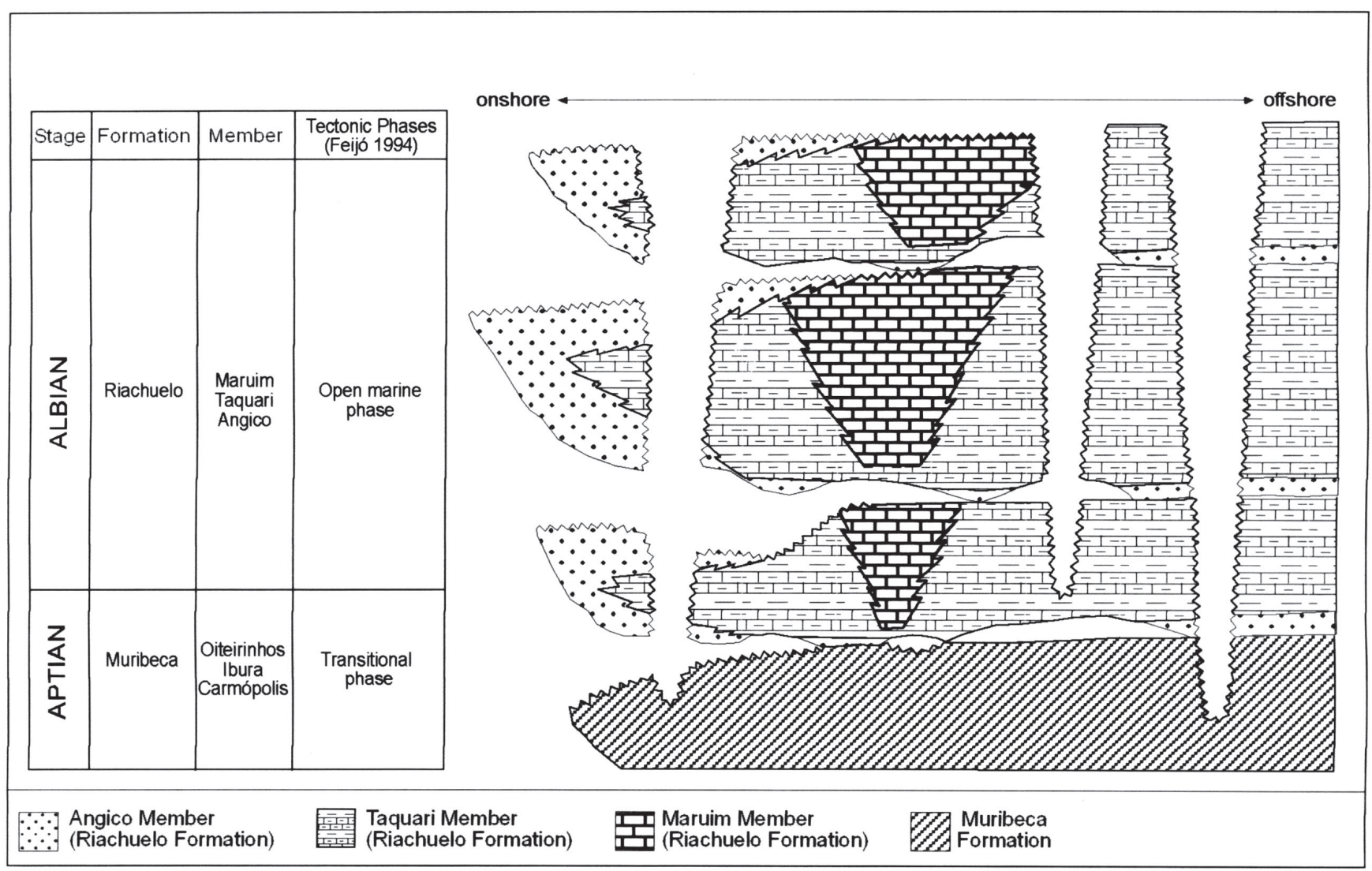

Figure 2. Lithostratigraphie scheme for the Aptian-Albian of the Sergipe basin (adapted from Mendes, 1994).

forms discrete groupings that are based on the characteristics (abundance) of the objects. The results are clearly displayed in dendrograms which, when combined, allowed assessment reasons for clustering. The Pearson coefficient (+/- 1) obtained from the relative abundance of palynomorphs, is used to yield a correlation matrix and to identify the relationship between the taxa. This coefficient reflects the presence or absence of similarity among the taxa. If coefficient approaching 1 implies a positive correlation and approaching -1, a negative correlation among the palynomorphs. Only the numerically and paleoecologically important taxa were used herein.

\section{Palynological Marine Index (PMI)}

This index was created by Helenes et al. (1998) to support in the interpretation of depositional environments. PMI is calculated using the formula: $\mathrm{PMI}=(\mathrm{Rm} / \mathrm{Rt}+1) 100$, where $\mathrm{Rm}$ is richness of marine palynomorphs (dinocysts, acritarchs and foraminiferal test linings) and Rt is the richness of terrestrial palynomorphs (pollens and spores) counted per sample. In the present study, the Rm and Rt were expressed as number of genera per sample. The genus level preferred because genera are more easily identified than species and the genera identified herein show the same environmental significance as species. The high values of PMI are interpreted as indicative of normal marine depositional conditions. When the samples have no marine palynomorphs the PMI value is 100.00 .

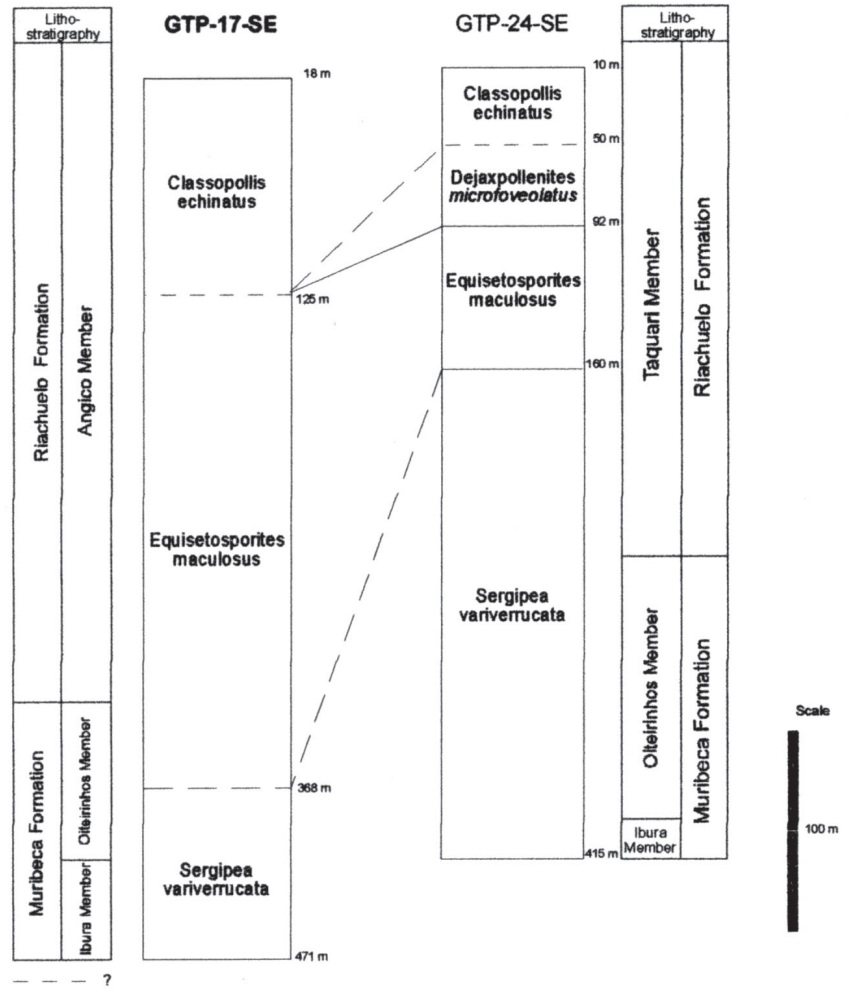

Figure 3. Correlation of the identified palynological zones and sub-zones between the two studied wells. 


\section{RESULTS}

The succession studied yielded a rich palynomorph assemblage, in particular of terrestrial components. However, the marine palynomorphs, notably in the upper part of the section of well GTP-24-SE, also show relatively high abundances.

The succession is strongly dominated by terrestrial palynomorphs (Figure 4). The pollen group, in particular gymnosperms, is by far the most abundant taxa. This group forms $84.7 \%$ of the total palynomorph assemblage in GTP17-SE and $61.8 \%$ in GTP-24-SE. In well GTP-17-SE the second most abundant group is the spores, which reach $8.9 \%$ of all palynomorphs. Well GTP-24-SE is characterized by a relatively high abundance of marine palynomorphs with $31.7 \%$ of the total palynomorphs. Fresh-water palynomorphs are rare, comprising less than $0.1 \%$ in both wells.

\section{Palynological assemblages}

R-mode cluster analysis, based on the abundance and composition of all 64 palynomorph genera found in wells GTP-17-SE and GTP-24-SE, revealed four superclusters that represent the palynological assemblages (PA) 1-4 (Figure 4). The major break between clusters 1 and 2 reflects clearly the separation of marine and terrestrial palynomorphs.

Palynological Assemblage 1. Palynological Assemblage 1 assemblage is composed of marine palynomorphs, with the exception of the fern spore genus Antulsporites. The assemblages contains Pseudoceratium, Prolixosphaeridium Cyclonephelium, Exochosphaeridium, Florentina, Trichodinium, scolecodonts, Spiniferites, palynoforaminifera, Oligosphaeridium, Systematophora and Antulsporites.

Nine out of seventeen genera of the dinocysts recorded in the succession are included in this assemblage, the majority of them belonging to the gonyaulacoid group. Generally, these genera indicate an open marine environment (neritic setting). Spiniferites is the most abundant dinoflagellate and, together with associated dinocysts such as Exochosphaeridium, Trichodinium and, Oligosphaeridium, indicative of open neritic conditions (Downie et al., 1971; Williams, 1977; Masure, 1984; Marshall \& Batten, 1988; Lana, 1997). However, the most abundant marine palynomorph is the palynoforaminifera group, which generally, is present in great abundance in nearshore environments (Tyson, 1995). However, according to Lana (1997), which analyzed Cenomanian-Turonian sediments from Potiguar Basin, northeast Brazil, this group shows higher abundance in middle and deep neritic than dinocysts. On other hand, the dinoflagellates were more abundant in shallow marine environments. Like the palynoforaminifera, Cyclonephelium are found in different bathymetry (shallow to middle neritic) (Lana, 1997). However, it seems an agreement among researchers (e.g. (Eshet et al., 1992; Lana, 1997), which high abundances of the genus Cyclonephelium are related to restricted marine environments under stress conditions.

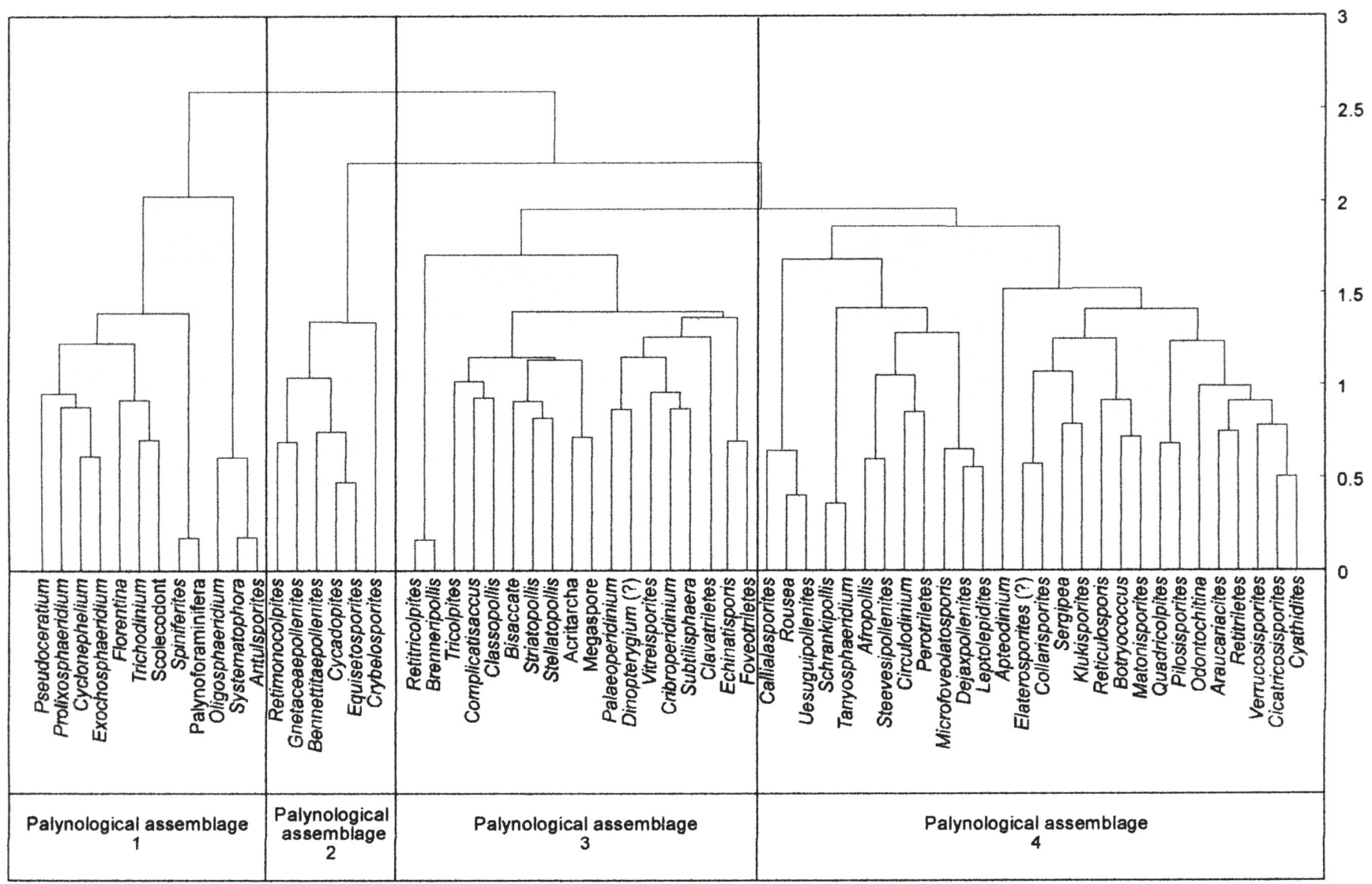

Figure 4. Dendrogram ( $r$-mode) of 64 genera from the two wells studied showing the four palynological assemblages. 
GTP-17

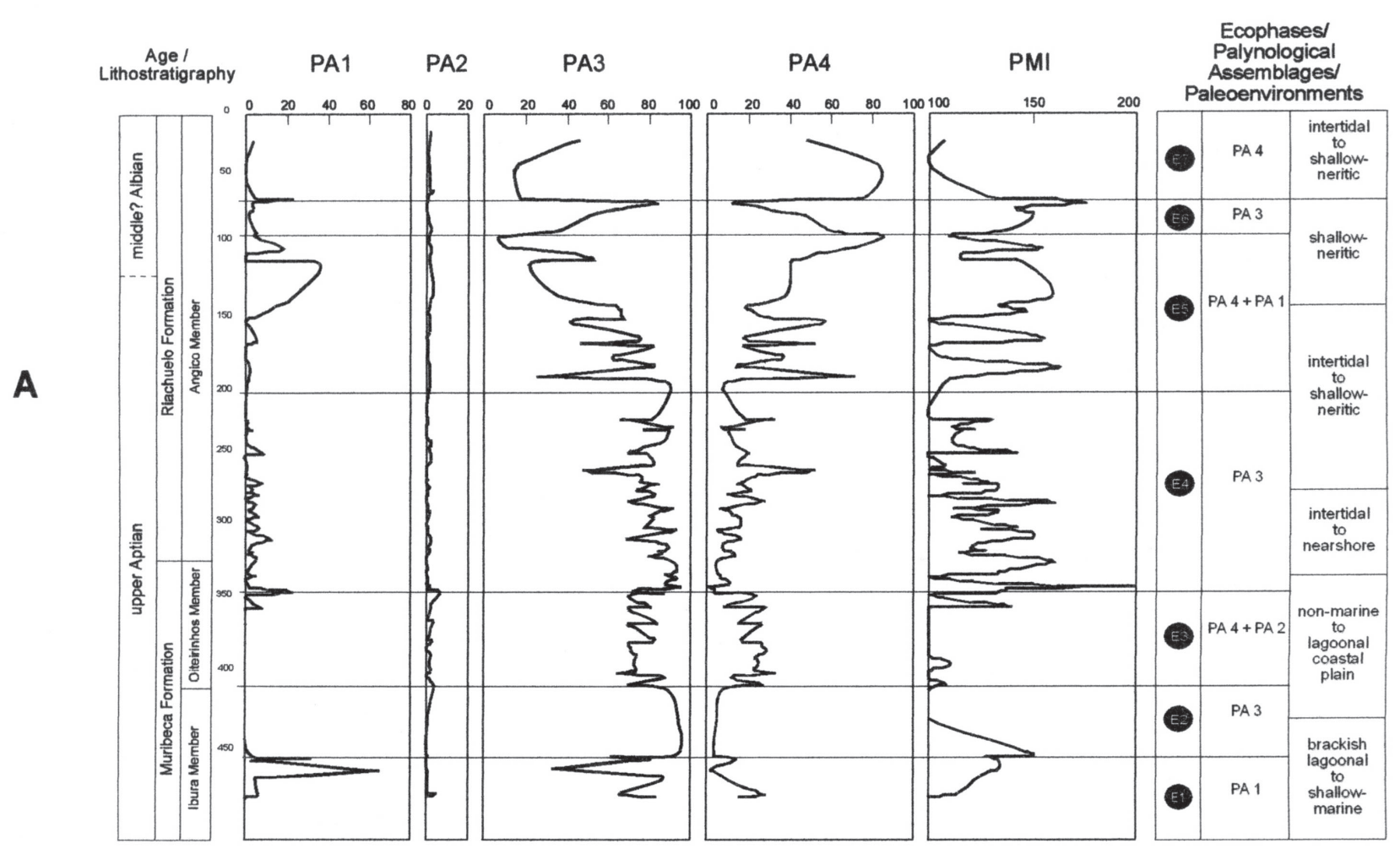

GTP-24

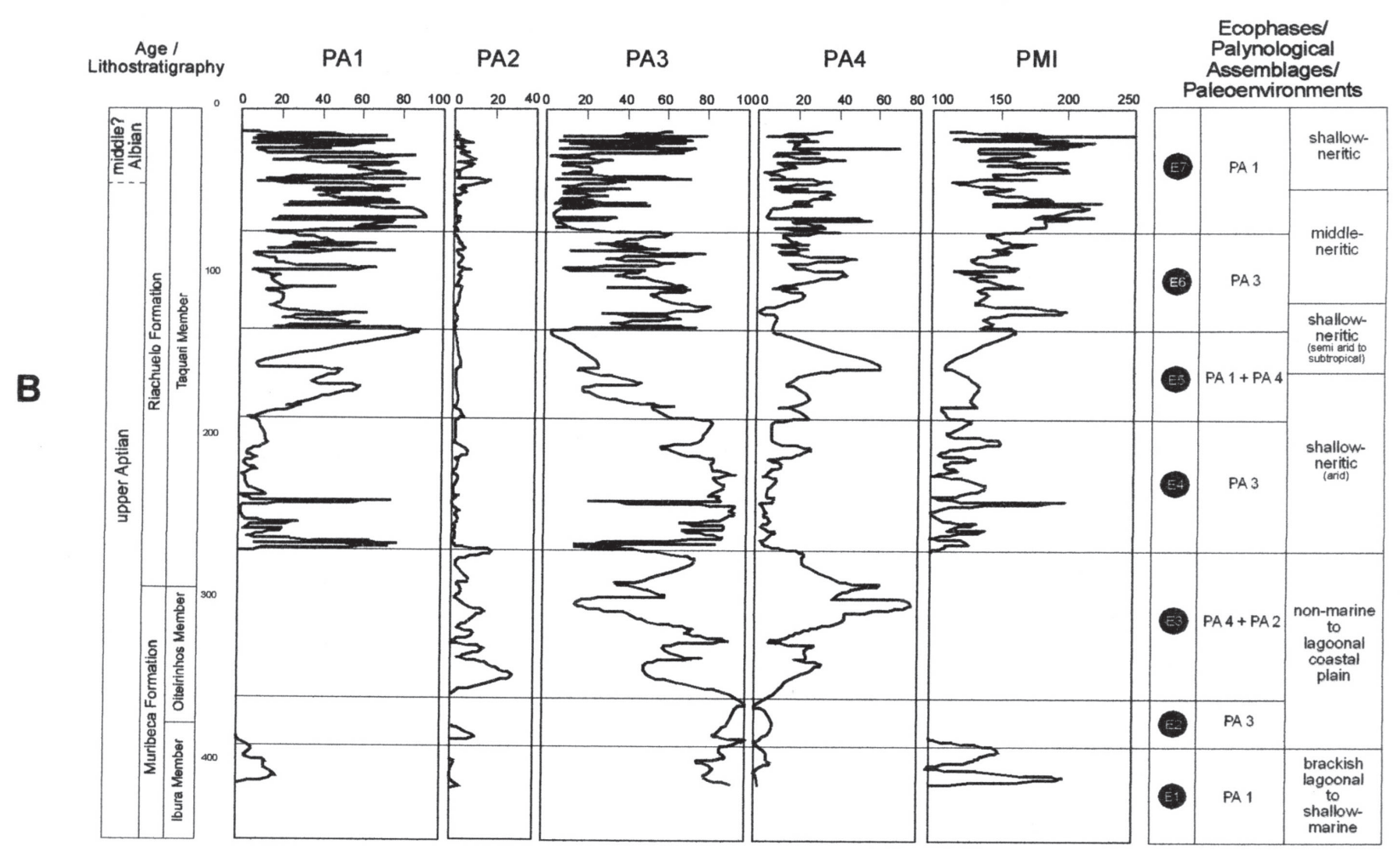

Figure 5. Stratigraphic distribution of palynological assemblages showing the Ecophases, PMI and paleoenvironments for well GTP-17 (A) and well GTP-24 (B). 
Palynological Assemblage 2. PA2 is composed only of terrestrial palynomorphs (e.g. Gnetaceaepollenites, Bennettitaepollenites, Cycadopites, Equisetosporites, Cyathidites). This assemblage has the lowest palynomorph abundance of the assemblages, with ephedroid types (Gnetaceaepollenites and Equisetosporites) being the most abundant. Their pollen grains are related to the modern gymnosperms Ephedra and Welwitschia (Gnetales), which are found in arid to semi-arid environments (Doyle et al., 1982; Arai \& Coelho, in press). As observed by Doyle et al. (1982), the correlation of Gnetaceaepollenites and Equisetosporites with Classopollis is negative (-0,19 and 0,15 respectively), which suggests that these genera are less tolerant of saline conditions than Classopollis.

Palynological Assemblage 3. PA3 shows the highest palynomorph abundance among the assemblages, with a dominance of Classopollis grains. The assemblage is mainly consisted of terrestrial palynomorphs (e.g. Brenneripollis, Tricolpites, Classopollis, bisaccates, Striatopollis, megaspore, Vitreisporites, Echitriletes). Classopollis was produced by the extinct conifer family Cheirolepidiaceae (Doyle et al., 1982) and dominated in regions with arid climates. Classopollis is most commonly recorded in nearshore marine-lagoonal environments and often associated with evaporites (Vakhrameev, 1970; Doyle et al., 1982; Hashimoto, 1995; Arai \& Coelho, in press). Classopollis shows low correlation with the other palynomorphs.

The presence of bisaccate (bisaccate-types and Vitreisporites) pollen in PA3 is contradictory because these pollen types are normally associated with temperate highland climates. However, Arai \& Coelho (in press) investigated samples from the Aptian-Albian of the Araripe Basin (north of the Sergipe basin) and observed a relatively high correlation between the bisaccate group and Classopollis. According to them, the bisaccates were transported by trade winds and that its abundance was influenced by a minor dilution in the arid periods (weaker terrestrial supply), whereas the terrestrial influx responsible for transport of the other palynomorphs was relatively weak.

The fern spores are also present in this assemblage, but in low abundances. The presence of megaspores reflects a nearshore environment. These spores are large, dense and thick-walled and not easily transported, so in general they are deposited near their source (Speelman \& Hills, 1980).

Four genera of dinocysts are recorded in PA3: Palaeoperidinium, Dinopterygium?, Cribroperidinium, and Subtilisphaera. Among them, the genus Subtilisphaera is by far the most abundant, being the second most abundant dinocyst genus in the assemblage. Generally, this genus is associated with marine environments with low salinity (Jain and Millepied, 1975). Moreover, the Subtilisphaera frequently occurs in restricted marine environments. This genus is also abundant in assemblages of low diversity (Arai et al., 1994; Lana, 1997). It represents $98 \%$ of the total of the four genera recorded in PA3, and correlation with other marine palynomorphs is very low.
Arai et al. (1994, 2000) proposed Subtilisphaera euecozones for the Early Cretaceous of the proto-Atlantic Ocean. These euecozones were originally identified in the Aptian-Albian of the Ceará basin (northern Brazil) and later in other continental marginal basins of Brazil. The Subtilisphaera Euecozone represents a predominance of the genus Subtilisphaera cysts making up an almost monospecific assemblage which reflects a worldwide dinoflagellates bloom in mid-Cretaceous epicontinental seas. However, according to Arai et al. $(1994,2000)$ this euecozone has not been confirmed in the Sergipe basin. Within five euecozones proposed by Arai et al. (1994), the Subtilisphaera spp. diluted by terrestrial palynomorphs Euecozone (type 5) would be the most comparable with the PA3. However, in the GTP-17-SE, the genus Subtilisphaera reaches $70.2 \%$ of all palynomorphs at $61.70 \mathrm{~m}$ characterizing the Subtilisphaera Euecozone (type 1). Like Subtilisphaera, Palaeoperidinium supports restricted marine conditions. Dinopterygium? and Cribroperidinium shows very low abundances.

Palynological Assemblage 4. PA4 is distinguished by the high diversity of fern spores and the high abundance of the genus Araucariacites. It is composed mainly of terrestrial palynomorphs (e.g. Callialasporites, Afropollis, Steevesipollenites, Leptolepidites, Sergipea, Klukisporites, Botryococcus, Matonisporites, Pilosisporites, Araucariacites, Verrucosisporites, Cicatricosisporites, Cyathidites).

Araucariacites is the second most abundant genus of the terrestrial palynomorphs. According to Doyle et al. (1982) it is related to a tropically-centered group, which is found in lowland deposits of the Early Cretaceous age. These authors mentioned that an increase in aridity resulted in a decline of Araucariacites abundance. This was also suggested by Arai \& Coelho (in press), who mentioned the fact that Araucariacites is characteristic of humid and subtropical to tropical climates. The genus shows a negative correlation with Classopollis $(-0,30)$, thus confirming this hypothesis.

PA4 contains the highest number of pteridophyte genera with Cicatricosisporites and Cyathidites being the most abundant. The fern spores have been largely related to humid conditions, based on modern distributions of the pteridophytes (Doyle et al., 1982; Lima, 1983; Arai \& Coelho, in press). Generally, high abundance of these spores is recorded in nearshore environments (Hughes \& MoodyStuart, 1967; Tschudy, 1969; Heusser \& Balsam, 1977, Mudie, 1982; Tyson, 1993). The genera Cicatricosisporites and Cyathidites have a negative correlation with Classopollis and ephedroid pollen.

Afropollis is the most abundant angiosperm pollen genus in the succession, although, it is recorded only in small amounts. This genus has been interpreted as typical of arid environments; however; just as the ephedroid group, Afropollis was less tolerant to saline soil conditions (Doyle et al., 1982). Afropollis also shows a negative correlation with Classopollis $(-0,24)$.

Four genera of dinocysts are found in PA4: 
Tanyosphaeridium, Circulodinium, Apteodinium, and Odontochitina, with Apteodinium being the most abundant. It has been interpreted as indicative of inner neritic conditions (Wilpshaar \& Leereveld, 1994), but others have suggested it could be found in open marine environments (Leckie et al., 1990). Like Cyclonephelium, the Circulodinium species are found in different bathymetry (shallow to middle neritic) (Lana, 1997), but they occur mainly in restricted marine environments under stress conditions. The other two genera are rare.

In this assemblage is included the only fresh-water palynomorph found in the succession, the genus Botryococcus. This genus is characteristic of fresh-water lacustrine, fluvial, lagoonal and deltaic facies (Traverse, 1955; Pocock, 1972; Herngreen et al., 1980; Batten \& Lister, 1988; Williams, 1992). According to Tyson (1995), the abundance of Botryococcus in marine sediments is usually low.

\section{Ecophases}

The application of ecophases was first introduced by Schuurman (1977), who defined as a recognizable step of the successive development of (palynological) assemblages (in Brugman et al., 1994). According to Brugman et al. (1994) the ecophases are characterized by the distribution of palynomorph taxa that reflect developments in the local vegetation or phytoplankton communities.

The stratigraphic distribution of the palynological assemblages allowed the definition of seven ecophases (Appendix 1 and Figure 5). These are recognized in both wells, but with some differences that are showed below in Appendix 1.

\section{Palynological Marine Index (PMI)}

The PMI curves of both wells show strong fluctuations (see Figure 5). The index ranges from 100.0, where marine palynomorphs are absent to 250.00 (in GTP-24-SE). This fluctuation reflects the major (low PMI values) and minor (high PMI values) influx in the area. However, in both curves there is an increase in abundance of marine palynomorphs upward. The average abundance in well GTP-24-SE is higher (138.90) than in GTP-17-SE (122.90). Most peaks of the PMI from both wells are related to an increase in abundance of palynoforaminifera and/or Spiniferites. However, in well GTP17-SE some of these peaks are related also to the presence of Subtilisphaera.

High values of PMI are found in ecophases where PA3 shows moderate abundance (see Figure 5A). This is best observed in well GTP-17-SE (ecophases 1 and 5). In well GTP-24-SE high PMI values are also found in ecophases characterized by PA1 (e.g., ecophases 1, 4, 5 and 7) (see Figure 5B).

\section{Paleoenvironments}

The paleoenvironmental reconstruction is based on an integration of data from palynological assemblages and the ecophases (Figure 5). The Aptian-Albian of the Sergipe Basin is characterized by a transgressional trend. The transition from a brackish lagoon to an open marine environment is recognizable in the data from palynological assemblages and the ecophases, and forms the basis for the subdivision of the succession into these major paleoenvironments. These two paleoenvironments are subdivided into six events that were mainly controlled by sea-level changes. The boundary between the two major paleoenvironments is marked by the first major transgression in the area.

\section{CONCLUSIONS}

The data confirm that the change from a brackish lagoon to open marine environment was controlled by sea-level during the deposition of the Muribeca Formation, and dominantly by a progressive sea-level rise during the beginning of the Riachuelo Formation deposition.

The succession studied in wells GTP-17-SE and GTP-24SE yielded a rich palynomorph assemblage, mainly represented by terrestrial components. The marine palynomorphs show high abundances in the upper part of well GTP-24-SE. Preservation of the palynomorphs is variable, ranging from moderate to well-preserved for the miospores and from poorly to moderately well-preserved for the dinocysts.

The gymnosperms are the most abundant group, as a consequence of the high abundances of the genus Classopollis in well GTP-17-SE. In well GTP-24-SE a relatively high abundance of marine palynomorphs is observed. Freshwater palynomorphs are rare.

The cluster analysis based on the abundance and composition of all 68 palynomorph genera revealed four superclusters, which represent different palynological assemblages (PA). The stratigraphic distribution of these assemblages allowed the definition of seven ecophases.

The Palynological Marine Index (PMI) curves confirm the progressively increasing marine influence in the region. However, the strong fluctuations of the curve reflect a continuous terrestrial influx to the area.

The paleoenvironmental history is strongly marked by the progressive late Aptian-middle Albian transgression into the area. The data confirm that the change from a brackish lagoon to open marine environment was controlled by sealevel during the deposition of the Muribeca Formation, and dominantly by a progressive sea-level rise during the beginning of the Riachuelo Formation deposition.

\section{REFERENCES}

Arai, M. \& Coelho, P.S.M. (in press). Aferição do valor paleoecológico dos palinomorfos fósseis por meio de análise estatística: exemplo a partir da microflórula Albo-Aptiana da Bacia do Araripe. Boletim de Geociências da Petrobras.

Arai, M.; Botelho Neto, J.; Lana, C.C. \& Pedrão, E. 2000. Cretaceous dinoflagellate provincialism in Brazilian marginal basins. Cretaceous Research, 21:351-366.

Arai, M.; Lana, C.C. \& Pedrão, E. 1994. Ecozona Subtilisphaera: Registro Eocretáceo de um importante episódio ecológico do Oceano Atlântico primitivo. Acta Geológica Leopoldinensia, 17:521-538. 
Batten, D.J. \& Lister, J.K. 1988. Evidence of freshwater dinoflagellates and other algae in the English Wealden (Early Cretaceous). Cretaceous Research, 9:171-179.

Brugman, W.A., Van Bergen, P.F. \& Kerp, J.H.F. 1994. A quantitative approach to Triassic palynology: the Lettenkeuper of the Germanic Basin as an example. In: A. Traverse. (ed.) Sedimentation of organic particles, Cambridge University Press, p. $409-429$

Carvalho, M.A. 2001. Paleoenvironmental reconstruction based on palynology and palynofacies analyses of upper Aptianmiddle Albian succession from Sergipe Basin, northeastern Brazil. Ruprecht-Karl Universität Heidelberg, Tese de Doutorado, $160 \mathrm{p}$.

Downie, C.; Hussain, M.A. \& Williams, G. L. 1971. Dinoflagellate cysts and acritarch associations in the Paleogene of southeast England. Geoscience and Man, 3: 29-35.

Doyle. J.A.; Jardine, S. \& Dorenkamp, A. 1982. Afropollis, a new genus of early angiosperm pollen, with notes on the Cretaceous palynostratigraphy and paleoenvironments of northern Gondwana. Bulletin des Centres de Recherches ExplorationProduction Elf-Aquitaine, 6: 39-117.

Erdtman, G. 1969. Handbook of palynology. $1^{\text {a }}$ ed. Copenhagen, Munksgaard (Scandinavian University Books), 486 p.

Eshet, Y.; Moshkovitz, S.; Habib, D.; Benjamini, C. \& Magaritz, M. 1992. Calcareous nannofossil and dinoflagellate stratigraphy across the Cretaceous-Tertiary boundary at Hor Harar, Israel. Marine Geology, 18:199-228.

Faegri, K. \& Iversen, J. 1966. Textbook of pollen analysis. $1^{\mathrm{a}} \mathrm{ed}$. Copenhagen, Munksgaard (Scandinavian university Books), $169 \mathrm{p}$.

Feijó, F.J. 1994. Bacias de Sergipe e Alagoas. Boletim de Geociências da Petrobrás 8: 149-161.

Hashimoto, A.T. 1995. Contribuição ao estudo do relacionamento da palinologia e a estratigrafia de sequências. Análise da seção do Cretáceo Médio/Superior da Bacia de Santos. Programa de Pós-Graduação em Geologia, Universidade Federal do Rio Grande do Sul, Dissertação de Mestrado, 130 p.

Helenes, J.; de-Guerra, C. \& Vásquez, J. 1998. Palynology and chronostratigraphy of the Upper Cretaceous in the subsurface of the Barinas area, western Venezuela. The American Association of Petroleum Geologists Bulletin, 82:1308-1328.

Herngreen, G.F.W.; Van Hoeken-Klinkenberg, P. M. J. \& De Boer, K. F. 1980. Some remarks on selected palynomorphs near the Jurassic-Cretaceous boundary in the Netherlands. In: INTERNATIONAL CONFERENCE， 4, 1976-1977. Proceedings, Lucknow, p.357-367.

Heusser, L.M. \& Balsam, W.L. 1977. Pollen sedimentation in the northwest Atlantic: effects of the Western Boundary Undercurrent. Marine Geology, 69:149-153.

Hughes, N.F. \& Moody-Stuart, J.C. 1967. Palynological facies and correlation in the English Wealden. Review of Palaeobotany and Palynology, 1:259-268.

Jain, K.P. \& Millepied, P. 1975. Cretaceous microplankton from Senegal Basin, NW Africa. 1. Some new genera, species and combinations of dinoflagellates. The Palaeobotanist, 20:22-32.

Koutsoukos, E.A.M. 1989. Mid- to Late Cretaceous microbiostratigraphy, palaeo-ecology and palaeogeography of the Sergipe Basin, northeastern Brazil. Council for National Academic Awards, Polytechnic South West, Plymouth, UK, Tese de Doutorado, 2 vols., 886 p.

Lana, C.C. 1997. Palinologia e estratigrafia integrada da seção Cenomaniano médio-Turoniano inferior da porção centro-leste da Bacia Potiguar, NE do Brasil. Programa de Pós-Graduação em Geologia, Universidade Federal do Rio Grande do Sul, Dissertação de Mestrado, 341 p.
Leckie, D.A.; Singh, C.; Goodarzi, F.; Wall, J.H. 1990. Organicrich, radioactive marine shales: a case study of a shallowwater condensed section, Cretaceous Shaftesbuty Formation, Alberta, Canadá. Journal of Sedimentary Petrology, 60(1):101117.

Lima, M.R. 1983. Paleoclimatic reconstruction of the Brazilian Cretaceous based on palynological data. Revista Brasileira de Geociências, 13:223-228.

Marshall, K.L. \& Batten, D.J. 1988. Dinoflagellate cyst associations in Cenomanian-Turonian "black shale" sequences of northern Europe. Review of Palaeobotany and Palynology, 54:85-103.

Masure, E. 1984. L'indice de diversite et les dominances des "communautes" de kystes de dinoflagelles; marqueurs bathymetriques; forage $398 \mathrm{D}$, croisiere 47 B. Bulletin de la Societe Geologique de France, 26: 93-111.

Mendes, J.M.C. 1994. Análise estratigráfica da seção neo-Aptiana/ Eocenomaniana (Fm. Riachuelo) na área do Alto de Aracajú e adjacências, Bacia de Sergipe/Alagoas. Programa de PósGraduação em Geologia, Universidade Federal do Rio Grande do Sul, Dissertação de Mestrado, 166 p.

Mudie, P.J. 1982. Pollen distribution in recent marine sediments, eastern Canada. Canadian Journal of Earth Sciences, 19:729747.

Ojeda, H.A.O. \& Fugita, A.M. 1976. Bacia Sergipe/Alagoas: geologia regional e perspectivas petrolíferas. In: CONGRESSO BRASILEIRO DE GEOLOGIA, 28, 1976. Resumos expandidos, Porto Alegre, SBG, p.137-158.

Ojeda, H.A.O. 1982. Structural framework, stratigraphy and evolution of Brazilian marginal basins. The American Association of Petroleum Geologists Bulletin, 66:732-749.

Pocock, S.A.J. 1972. Palynology of the Jurassic sediments of western Canada. Part 2: Marine species. Palaeontographica Abteilung B, 137:85-153.

Regali, M.S.P. \& Santos, P.R.S. 1999. Palinoestratigrafia e geocronologia dos sedimentos Albo-Aptianos das bacias de Sergipe e de Alagoas. In: SIMPÓSIO SOBRE O CRETÁCEO DO BRASIL, 5, 1999. Resumos expandidos, Serra Negra, UNESP, p.411-420.

Schuurman, W.M.L. 1977. Aspects of Late Triassic palynology. 2. Palynology of the 'Grès et Schiste à Avicula contorta' and 'Argiles de Levallois' (Rhaetian) of northeastern France and southern Luxembourg. Review of Palaeobotany and Palynology, 23:159-253.

Seeling, J. 1999. Palaeontology and biostratigraphy of the macroinvertebrate fauna of the Cenomanian-Turonian transition of the Sergipe Basin, northeastern Brazil-with systematic description of bivalves and echnoids. Ruprecht-Karl Universität Heidelberg, Tese de Doutorado, 163 p.

Speelman, J.D. \& Hills, L.V. 1980. Megaspore paleoecology: Pakowki, Foremost and Oldman formations (Upper Cretaceous), southeastern Alberta. Bulletin of Canadian Petroleum Geologists, 28:522-541.

Traverse, A. 1955. Occurrence of the oil-forming alga Botryococcus in lignites and other Tertiary sediments. Micropaleontology, 1:343-350.

Tschudy, R.H. 1969. Relationship of palynomorphs to sedimentation. In: R.H. Tschudy, \& R.A. Scott (eds.) Aspects of Palynology, Wiley, p.79-96.

Tyson, R.V. 1995. Sedimentary Organic Matter: organic facies and palynofacies. 1 ed., London, Chapman \& Hall, 615p.

Tyson, R.V., 1993. Palynofacies analysis. In: D.J. Jenkins (ed.) Applied Micropalaeontology, Kluwer Academic Publishers, p.153-191. 
Uesugui, N. 1979. Palinologia; técnicas de tratamento de amostras. Boletim Técnico da Petrobras, 22:229-240.

Vakhrameev, V.A. 1970. Range and paleoecology of Mesozoic conifers. The Cheirolepidiaceae. Paleontology Journal 41:1125.

Williams, G.L. 1977. Dinocysts. Their classification, biostratigraphy and palaeoecology. Oceanic Micropalaeontology 2:1231-1325.
Williams, G.L. 1992. Palynology as a paleoenvironmental indicator in the Brent Group, northern North Sea. In: A.C. Morton, R. S. Haszeldine, M.R. Giles \& S. Brown (eds.) Geological Society of London Special Publication, 61:203-212.

Wilpshaar, M. \& Leereveld, H. 1994. Palaeoenvironmental change in the Early Cretaceous Vocontian Basin (SE France) reflected by dinoflagellates cysts. Review of Paleobotany and Palynology, 84(1/2):121-128. 
Appendix 1. The identified ecophases of the wells GTP-17 and GTP-24.

\begin{tabular}{|c|c|}
\hline Ecophases (E) & Main characteristics \\
\hline E1 & $\begin{array}{l}\text { Relatively high abundance of marine palynomorphs of PA1. In well GTP-17 a PA1 is composed essentially of } \\
\text { palynoforaminifera. In well GTP-24-SE palynoforaminifera are also dominant, although dinocysts (Spiniferites) } \\
\text { are present in moderate abundances. }\end{array}$ \\
\hline E2 & $\begin{array}{l}\text { Absolute dominance of PA3, in particular the genus Classopollis. Marine palynomorphs are rare, and are found } \\
\text { only in the lower part of the ecophase. }\end{array}$ \\
\hline E3 & $\begin{array}{l}\text { The dominance of PA4, in particular by Araucariacites together with the highest abundance of the palynomorphs } \\
\text { from PA2. Rare occurrence of marine palynomorphs. In both wells the marine palynomorphs not reach the } \\
\text { minimum values for statistical evaluation. }\end{array}$ \\
\hline E4 & $\begin{array}{l}\text { Increase of the abundance of palynomorphs from PA3 due mainly to Classopollis. The great abundance of these } \\
\text { terrestrial palynomorphs from PA3 reflects a high proportion of fine siliciclastic sedimentation, especially shales. } \\
\text { Within of this ecophase occur the first registers of peaks in abundance of Subtilisphaera. However, in this } \\
\text { ecophase, the terrestrial palynomorphs, in particular Classopollis, are the most abundant characterizing } \\
\text { Subtilisphaera spp. diluted by terrestrial palynomorphs Euecozone (type 5) from Arai et al. (1994). }\end{array}$ \\
\hline E5 & $\begin{array}{l}\text { Progressive increase of marine palynomorphs from PA1, mainly due to Spiniferites, Exochosphaeridium, and } \\
\text { Trichodinium associated with fern spores (Cyathidites and Cicatricosisporites) and Araucariacites from PA4. At } \\
\text { the base of this ecophase occur peaks in abundance of Subtilisphaera (euecozone type 5) that are progressively } \\
\text { replaced for dinocysts from PA1. Of all the dinocysts recorded in the succession, these marine components are } \\
\text { the ones that are most clearly indicative of open marine environments. Therefore, their abundance in this } \\
\text { ecophase is strong evidence of the beginning of a transgressive phase. }\end{array}$ \\
\hline E6 & $\begin{array}{l}\text { Percentage of Classopollis (PA3) increases again, but remains lower than in ecophases } 2 \text { and } 4 \text {. This, together } \\
\text { with a moderate abundance of marine palynomorphs from PA1 (particular in well GTP-24-SE), indicates that the } \\
\text { terrestrial influx was not as strong as in Ecophase } 4 \text {. In the GTP-17-SE well the strong terrestrial input in this } \\
\text { phase allowed the occurrence of Subtilisphaera characterizing the Subtilisphaera spp. diluted by terrestrial } \\
\text { palynomorphs Euecozone (type 5). Moreover, in spite of the evidence of a moderate regression, the environment } \\
\text { is still characterized as open marine. }\end{array}$ \\
\hline E7 & $\begin{array}{l}\text { Characterized by high abundance and diversity of marine palynomorphs from PA1 indicating an open marine } \\
\text { environment. This is distinguished mainly in well GTP-24-SE. The abundance of PA1 in well GTP-17-SE is } \\
\text { relatively low, with PA4 being the most abundant. In fact, in both wells Araucariacites pollen grains from PA4 are } \\
\text { the most characteristic land-derived elements. The low abundances of PA1 in well GTP-17-SE are taken to } \\
\text { reflect a proximal facies of the Angico Member. Furthermore, as mentioned previously, at the upper part of this } \\
\text { ecophase in the GTP-17-SE, occur very high abundance of Subtilisphaera reaching } 70.2 \%(61,7 \mathrm{~m}) \text { of all } \\
\text { palynomorphs. This characterizes the Subtilisphaera Euecozone (type 1) in the Sergipe basin. }\end{array}$ \\
\hline
\end{tabular}

